\title{
Raymond Durgnat and A Mirror for England
}

\author{
ROBERT MURPHY
}

If clearly marked personal style is one's criterion of interest, then few British films reward the concern given to such directors as, say, Dreyer, Buñuel, Franju and Renoir. But other criteria of interest exist, whereby many of the subtlest meanings behind a personal style may be related to the collective vision of a particular tradition, period, background or 'school'. It's logical and usual to consider even impersonal and anonymous artworks as an expression of a general consensus (A Mirror for England, p. 4).'

Raymond durgnat's A Mirror for England: British Movies from Austerity to Affluence, which deals extensively with British films of the I950s, was written in the mid-1960s and was published in 1970. Given the shifts in attitudes over the past thirty years - in society generally as well as in the little world of film studies - one might expect the judgments expressed there, the choices of what is important, to have become dated and irrelevant. If one reads Roy Armes's A Critical History of British Cinema, which was published in 1978 , one is propelled into a time warp where academics with long hair wore tank tops and flared jeans, and had posters of La Hora de los Hornos on their walls. Armes draws inspiration from a deadly cocktail of Althusserian Marxism and the languid snobbery of C. A. Lejeune to take to task an industry which 'has never created an adequate working

\footnotetext{
Raymond Durgnat died in June 2002 at the age of 69 . The Australian online journal Senses of Cinema devoted a substantial part of its June issue to a Festschrift planned to honour his seventieth birthday <www.sensesofcinema. com>.

I am Professor in Film Studies at De Montfort University. My first teaching experience was a one-term class at Morley College in Lambeth on British cinema in the I940s. The students were refreshingly enthusiastic and most of them enrolled for a second term on British cinema in the I950s. Unfortunately this was a period I was weak on and I will remain eternally grateful to one of the students - Richard Dacre, who runs the Flashbacks shop in Soho - who agreed to teach it with me; and to Raymond Durgnat's $A$ Mirror for England which proved to be a mine of useful and inspiring information about a period of British cinema no one else seemed to take seriously. My most recent book is British Cinema and the Second World War (Continuum, 2000). Robert Murphy.
} 
context for those who wish to question the dominant stylistic approaches or provide stimulus for social change, with the result that there has been virtually no avant-garde film-making and no effective militant cinema in Britain'.2 Durgnat is much less time-bound and his analysis of British cinema has proved remarkably prescient. A Mirror for England deals with topics such as national identity and the decline of empire, realism and romanticism, politics, class, masculinity, sexuality and social problems. Durgnat writes appreciatively about Hammer and Gainsborough, purveyors of despised melodramas and horror films; he takes Powell and Pressburger seriously and gives sympathetic consideration to directors like Val Guest, Roy Baker, J. Lee Thompson, Basil Dearden, Roy and John Boulting and John Guillermin who were regarded as irredeemably mediocre by other critics. ${ }^{3}$ Thirty years before the James Bond films found an intellectual champion in James Chapman and Andrew Spicer made a detailed study of British male types, Durgnat divided the cads from the cadets, the gentlemen from the players and argued 'it's only natural to like Ian Fleming's naughty hero better than the male nannies of sweetness and light who deprecate him' (pp. $152-3){ }^{4}$

A Mirror for England was popular and well reviewed - by David Pirie in Time Out (IO-17 June 1973) and Charles Barr in Monogram (issue 3 in I972), for example - but it was never afforded the academic respectability granted Pirie's A Heritage of Horror (1973) and Barr's Ealing Studios (1977). This was partly a matter of timing. In 1970 when film theory was young and determined to embrace the avant garde, A Mirror for England, with its patriotic red, white and blue cover, its presumptuous claims for directors whose careers seemed to have slipped into terminal decline and its focus on the stuffily conservative i950s, seemed to dwell unnecessarily on a best-forgotten past. ${ }^{5}$

For those unfamiliar with the field and unwilling to devote the time and attention to learning about it which $A$ Mirror for England demands, it is not an easy book to penetrate. The film enthusiasts who read Films and Filming, where Durgnat tried out many of his ideas and subjects for the book, would have seen most of the films he discusses on their original cinema release and were sophisticated enough to appreciate his mischievous juxtapositions such as that comparing Pat Jackson's masterpiece of wartime realism, Western Approaches (1944), with Don Chaffey's pre-Roman epic, Jason and the Argonauts (1963). But this was an ageing and shrinking readership, and for the academic mind unprepared to follow the convoluted logic of Durgnat's method, the book must have seemed inexcusably haphazard and untidy.

Durgnat warns us in his introduction that he intends to concentrate "less on evaluating the texture of films than on critical exegesis of certain themes, 
undercurrents and overtones' (p. 3) This is a book which dispenses with narrative or chronological progression. There are no neat divisions into directors or writers or studios or genres. Instead of histories of Ealing and Gainsborough, career profiles of John Mills and Richard Attenborough, assessments of the achievements of Asquith and Cavalcanti, there are chapters with headings like 'Points of View' and 'Our Glorious Heritage' divided into mystifying sub-headings such as 'Gangrene-British Style' and 'The Impotence of Being Earnest'. The Dam Busters (1954) and Carve Her Name With Pride (1958) disconcertingly rub shoulders with They Can't Hang Me (1955), Violent Playground (1958) and Beat Girl (1960) ('System as Stalemate'). Most of Powell and Pressburger's wartime films appear alongside Asquith's The Demi-Paradise (1943), Hitchcock's The Skin Game (1931) and Lean's Great Expectations (1946) in 'The Nine Lives of Colonel Blimp'; the post-war films turn up in 'Between Two Worlds' where Powell is classified as a romantic alongside Lean, Cavalcanti and John Guillermin. For Durgnat's views on World War II films one has to flit between 'Tunes of Bogey', 'The Lukewarm Life', 'System as Stalemate', 'The Doctored Documentary', 'Stresses and Strains', 'The Glum and the Guilty', 'Gangrene - British Style' and 'The British Constitution'. What one finds is valuable and interesting and uncontaminated by the prevailing prejudices of the time but it requires a degree of diligence to extract it.

In the 1980 s as the revival of interest in British cinema began to gather momentum, the value of $A$ Mirror for England (then still widely available in second-hand bookshops and the shelves of public libraries) began to be recognised. In I986 Julian Petley wrote about an unmapped British cinema beyond the small canon of culturally respectable realist films and expressed the hope that in time the films he discusses 'would look less like isolated islands revealing themselves, and more like the peaks of a long submerged lost continent'. ${ }^{6}$ A Mirror for England, with its passages on morbid thrillers, gothic horror films and exotic melodramas, was one of the few sources one could turn to as a guide to this legacy of lost films. But Durgnat's enthusiasm for forgotten films from the realist mainstream such as Anthony Asquith's Orders to Kill (1958) and Jack Lee's Circle of Deception (1960), Val Guest's 80,000 Suspects (1963), J. Lee Thompson's Woman in a Dressing Gown (1957) and No Trees in the Street (1958), and Roy Baker's Passage Home (1955) and A Night to Remember (1958), troubles and contradicts the idea that the most exciting and valuable part of British cinema was that which defied the realist ethos.

Durgnat emerges, despite his enthusiasm for Terence Fisher's gothic horror films and the artistically extravagant work of Michael Powell and Emeric Pressburger, as a rationalist rather than a romantic. He had described 
himself seven years earlier as 'a Socialist Freudian Epicurean stoic scientific humanist critic' and his experience of growing up during the war and undergoing national service left him with a tough-minded resistance to mystical evocations of English society. ${ }^{7}$ This can be seen in his somewhat harsh treatment of Humphrey Jennings, where his empathy is held firmly in check by his suspicion of the underlying ideology. In A Diary for Timothy (1945), for example, 'A scattering of faces, of observations extremely beautiful in themselves, and, to this writer, tearingly nostalgic of some intense childhood moments, are pressed into the service of a quiet near-jingoism which altogether understandable in war, cannot achieve more than secondrate artistic status' (p. 15).

One of Durgnat's strengths is his awareness of the world beyond the film and his concern with how well or how distortedly it has been represented, of 'how far to match a film's picture of reality against other evidence as to the real nature of this reality' (p. 9). In analysing I Believe in You (195I), for example, a classic 'do-gooding' social-problem film, he illustrates how the integrity of the film-makers (Basil Dearden and Michael Relph) and the conviction of the actors give it a rewarding and satisfying complexity. The film's simplistic ethos displays a 'paternalism more marked than that of the probation service itself' and 'subsists in the supposition that what lads need is relationships with firm and responsible father- and mother-figures from the upper-classes'. In the real world, Durgnat argues, 'Much delinquency isn't the product of personal misfits at all but of emotionally quite normal attachments to a sub-society poorly integrated with the sub-society from which the judiciary springs'. It's unlikely that Dearden and Relph shared such a view, but in the performance of the young Joan Collins, whose 'grace, vigour and insolent savoir-vivre validate her character's subversive attitudes', the expression of this contradictory interpretation of delinquency finds a powerful and persuasive voice (p. 138).

Durgnat claims that he wants to 'underline unnoticed ambivalences' in films he 'would like to promote from the ranks of mediocrity to the status of interesting or poignant films, and even, occasionally, a minor classic' (p. 9). But he also offers new ways of looking at well-established films. David Lean's Great Expectations, for example, 'trembles on the brink of being a classic Marxist fable about bourgeois "confusionism" with Miss Havisham as the vampire of upper-middle-class snobbery and frigidity, accepting gratitude, giving nothing' (pp. 22-3). He challenges the view that 'run-of-the-mill movies never say anything, that vivid or insightful remarks or situations are a monopoly of a few prestigious individuals' (p. 4). But he is no iconoclastic cultist casting out false idols from the temple of British cinema and installing 
new gods. His 'First Draft Pantheon' of British films is stuffed with worthy theatrical adaptations like The Browning Version (I95I) and The Long and the Short and the Tall (I960), artistically fashionable films such as Antonioni's Blow Up (1966) and Losey's King and Country (1964) and established classics like Brief Encounter (1945) and Odd Man Out (1946). Lower down, Black Narcissus (1947) and Tiger in the Smoke (1956) make their appearances but there are notable omissions - A Canterbury Tale (I944) and The Small Back Room (1949), The Cruel Sea (1952) and A Town Like Alice (1956) - and the only costume melodramas to make it into the top one hundred are Losey's The Gypsy and the Gentleman (1957) and Dickinson's Queen of Spades (1948) and Gaslight (1940).

The high estimate put on the English films of Joseph Losey, the determination to disrupt the aura of reverence around the British Documentary Movement, the questioning of the importance of Free Cinema and scepticism about the status of The Third Man (1949) as a masterpiece, were shared by other young critics, particularly the auteurists clustered around the journal Movie. In the early ig6os auteurism provided a battering ram to shatter the hallowed portals of the critical establishment and Durgnat was intent on attacking the British Film Institute and its house journal Sight and Sound. In a wide-ranging polemic against prevailing cultural attitudes he complained that: "The trouble with the S \& S non-theory is that it is an assortment of prejudices and habits which thinks it is the broadest possible, the biggest and best, range of tastes. Actually, its scope, minimal in the first place, is not increased but diminished by the play of the contradictions beneath the mask of tolerant eclecticism'.

But Durgnat's relationship with auteurism is a complex one. He was influenced more by the left-wing populism of Positif than the politique des auteurs espoused by Cahiers du Cinéma, and was sceptical of the over-emphasis on style and the over-valuing of Hollywood directors by English auteurists, but he was even more dubious about the opposite camp of 'commitment' critics who wanted an openly political cinema and retained the Documentary Movement's hostility to popular commercial cinema. He argues for an auteurism capable of coming to terms with British cinema: 'Even within the assumptions of auteur theory, I would suggest that it's absurd to notice such Hollywood conformists as Hawks, McCarey and Walsh, yet deny equally high honours to, say, Roy Baker, Michael Powell and Terence Fisher' (p. 4). Indeed, the final chapter of the book, 'Romantics and Moralists', makes a convincing auteurist case not only for Fisher, Powell and Baker, but for Basil Dearden, Val Guest, J. Lee Thompson, Roy and John Boulting, David Lean, Launder and Gilliatt, Alberto Cavalcanti, John Guillermin, Anthony 
Asquith and Thorold Dickinson. (Other directors, notably the 'pessimists' Carol Reed and Robert Hamer, are given their due elsewhere in the book.) He is robust in favourably contrasting denigrated British directors with their fondly indulged Hollywood counterparts, but makes no attempt to disguise the thin soil of British film culture. While restoring Powell and Pressburger's The Tales of Hoffmann (195I) to its rightful place as a minor classic, and acknowledging the brilliance of Heckroth's designs, he exposes the wobbly philosophical underpinning upon which it is constructed.

One need only compare the awkward way in which humans and puppets mingle in a symbolic quadrille with the similar mixture in the night club scene in L' Herbier's La Nuit fantastique. L' Herbier, however academic, had grown up within a climate infected by Surrealism, by the sombre, toughly Marxist poetry of PrévertCarné, by Delluc, by Vigo. Powell-Heckroth have as inspirational trampoline the visual culture of Ye Olde Junke Shoppe. (p. 21I)

Though he went on to write books on Jean Renoir, Alfred Hitchcock, Georges Franju, Luis Buñuel and King Vidor, who would now be acknowledged as film artists, Durgnat shared the same enthusiasm for popular culture and scepticism about the relevance of high-art criteria which Lawrence Alloway had expressed in 'The Long Front of Culture' back in I959: 'Mass production techniques, applied to accurately repeatable words, pictures and music, have resulted in an expendable multitude of signs and symbols. To approach this exploding field with Renaissance-based ideas of the uniqueness of art is crippling. Acceptance of the mass media entails a shift in our notion of what culture is." $A$ Mirror for England attempts the ambitious task of dealing with the cultural significance of a whole tradition of film-making. In I947 when Siegfried Kracauer had attempted to examine a period of German cinema in From Caligari to Hitler, he had constructed an over-arching theory - that German films of the I920s manifested the internal sickness of German society and presaged the rise of Hitler - to link together the disparate films he discusses. ${ }^{10}$ Durgnat sets himself looser parameters, offering 'a survey of some major recurring themes in British movies between 1945 - being the end of the war and the election of the post-war Labour government - and 1958 , when the success of Room at the Top marks the breakthrough of a new cinema'.

In From Caligari to Hitler, Kracauer's analysis is distorted by his need to strong-arm films into becoming symbols of the zeitgeist. Durgnat's mosaic of essays is held together by more tenable and durable principles:

I that films don't have to be masterpieces to be worth writing about;

2 that national cinema is intrinsically interesting as a window onto the society from which it emerges; 
3 that auteurism could be a useful concept for analysing films made by the same director even when they did not reflect a coherent world view and a personal vision;

4 that it is possible to discern patterns across groups of films which did not necessarily share the same director, or the same production company or even the same genre.

They are principles which continue to be useful for the study of British cinema.

In Films and Feelings Durgnat admits that 'It is surprisingly easy to deploy certain exegetical techniques as to make extremely simple and dreary works of art sound interesting'. II He vows to abstain from such specious intellectualism, but in A Mirror for England, where he seeks to prove 'that artworks not of the highest textual quality' nevertheless deserve thematic exegesis, and that 'many fascinating moments occur in generally mediocre films', the temptation is sometimes too great (p. 4). In summing up the work of his mentor, Thorold Dickinson, for example, he makes claims for a depth and complexity which is not obviously apparent:

Dickinson's films, baroque in their diversity, in their volatile mixture of strength and adaptability, are baroque also in a deeper sense. Superficially, the rationale of the style would seem to be its conjuncture of sensitivity and showmanship. One deploys one's effects to render nuances of feeling and to move the spectator. But their mercuriality is such that, sensed as one would a painter's or a poet's style, the cinematographic quality becomes that of an imperious form overlying assertions and contradictions whose synthesis must be radical uncertainty. We are led straight towards the existentialist paradox, of being as not-being, of life's discontinuities as freedom fraught with anguish and, curiously, a sense of fate. (p. 233) 12 $^{2}$

On the other hand, Durgnat's comment on a still neglected director, Roy Baker - 'The barbed force of Baker's films lies in his feeling for evil as both result of injustice, and an impersonal force which, lurking in the nature of man, takes him over' - is eloquent and persuasive (p. 24I). ${ }^{13}$ While even Dickinson's admirers might balk at Men of Two Worlds (1946) being included among the top fifty British films, Durgnat's comparison of Cavalcanti's They Made Me a Fugitive (1947) with Howard Hawks's The Big Sleep (1946) and his praise for David MacDonald's The Brothers (1947) for dealing effectively with issues explored in American Westerns seems judicious, and his claims for the films of Powell and Pressburger now look surprisingly modest.

A Mirror for England has acquired an unjustified reputation for plot and character errors. It tends to be assumed that, prior to the widespread availability of video, books were written from dimly remembered cinema 
screenings. But Durgnat, as one of the small group of students under Thorold Dickinson's tutelage at the Slade School of Art, had privileged access to National Film Archive prints and, particularly for those films he analyses in detail, characters, plot and meaning are accurately and perceptively dealt with. Inevitably, in covering some 750 films, there are a few mistakes: it was Googie Withers herself, not the character she plays in The Loves of Joanna Godden (1947), who upped sticks and emigrated to Australia; in They Came to a City (I944) not all the representatives of society turn their back on the utopian city; James Mason in The Man in Grey (1943), beats his mistress (Margaret Lockwood) to death, not his wife (Phyllis Calvert); Rosamund John is mistaken for Joy Shelton in Waterloo Road (1944), Phyllis Calvert for Anne Crawford in Millions Like Us (1943); The Proud Valley (1939) metamorphoses into Pastor Hall (1940), and the list of illustrations turns Donald Sinden into Denholm Elliott. But these are the sort of mistakes which should have been picked up and corrected by a good editor and, irritating though they might be, they rarely invalidate Durgnat's analyses.

In an editorial for the stimulating but short-lived journal Motion, Durgnat argues that 'At its best, the thoroughly efficient, apersonal commercial film attains the eloquence and beauty of a myth. It is the sentiments of a group crystallized into dramatic terms, and shared ${ }^{14}$ But he is always aware that commercial films are the imperfect products of a system designed to make money not to create art, and at times his frustration with the way in which some of his chosen films miss their chances sometimes breaks out into an alternative scenario (as with Roy Baker's Flame in the Streets (I96I)) where contradictions and complexities are resolved in a more creative, adventurous and satisfying way. This sense of cinema as fluid and unfixed runs counter to the idea of cinema as an unchanging arena of masterpieces and failures and is considerably more liberating for the historian. Though most of the films, the directors, the issues and concerns Durgnat excavates have subsequently been dealt with in more detail elsewhere, $A$ Mirror for England remains relevant because it views the past not as a drab catalogue of mistakes which must be erased or corrected by the creation of a more rigorous type of cinema, but as a cornucopia of riches to be enjoyed and shared and drawn upon as a way of illuminating life and art.

\section{Notes}

I All page references are to $A$ Mirror for England unless otherwise stated.

2 Roy Armes, A Critical History of British Cinema (Secker \& Warburg, I978), pp. 3-4 .

3 Mirror's treatment of Powell and Pressburger predates the collections of interviews and essays edited by Kevin Gough Yates in I97I as Michael Powell in Collaboration with Emeric 
Pressburger (British Film Institute) and by Ian Christie in 1978 (Powell, Pressburger and Others, British Film Institute), though it is preceded by Ian Johnston's 'A Pin to See the Peepshow' in Motion 4 (February 1963), and Midi-Minuit Fantastique, 'Dossier Michael Powell' (October 1968). There is a seminal essay on Powell in Movie by O.O. Green (Autumn I965); 'Green' is Durgnat under another name.

4 James Chapman, Licence to Thrill: A Cultural History of the James Bond Film (I.B. Tauris, 1999) and Andrew Spicer, Typical Men: The Representation of Masculinity in Popular British Cinema (I. B. Tauris, 200I).

5 The idea that British cinema is too dull to be worth the serious consideration of intellectuals lives on. See, for example, Gilbert Adair, 'One of those Films Destined to be Forgotten', Independent on Sunday (I2 November 2000).

6 Julian Petley, 'The Lost Continent', in Charles Barr (ed.), All Our Yesterdays (British Film Institute, 1986), p. I18.

7 'Standing Up for Jesus', Motion 6 (Autumn 1963), p. 4 I.

8 'Standing Up for Jesus', p. 39. For Durgnat's relationship to other critics of his generation, see Jonathan Rosenbaum,'Raymond Durgnat', and Raymond Durgnat, 'Apologia and AutoCritique', Film Comment (May 1973), pp. 65-9; and 'Critical Debates', ch. 3 of Robert Murphy's Sixties British Cinema (British Film Institute, 1992).

9 Lawrence Alloway, 'The Long Front of Culture', Cambridge Opinion 17 (1959), reprinted in Suzy Gablik and John Russell (eds), Pop Art Redefined (Thames \& Hudson, I982).

Io Siegfried Kracauer, From Caligari to Hitler: A Psychological History of the German Film (Princeton University Press, I947).

II Films and Feelings (Faber \& Faber, 1967), p. I5.

I2 See also Jeffrey Richards, Thorold Dickinson (Croom Helm, 1986). Richards shares Durgnat's high regard for Dickinson, but in a book-length study has the space to discuss his weaknesses, too.

I3 See Peter Hutchings, 'Roy Ward Baker and Authorship', in Justine Ashby and Andrew Higson (eds), British Cinema, Past and Present (Routledge, 2000). Baker changed his name to Roy Ward Baker in 1967.

I4 'Editorial', Motion 3 (November 1962), p. 4.

\section{Durgnat on British cinema: a select bibliography}

Durgnat's publishing range is vast - from Marilyn Monroe to Georges Franju, from animation to film noir: I have included here only his essays and articles on British cinema.

'A Salute to Slaughter', Ark: Journal of the Royal College of Art 30, 196I-62.

'Puritans Anonymous', Motion 6 (Autumn I963), p. 3.

'Standing Up for Jesus', Motion 6 (Autumn I963), pp. 25-42.

'Old Wine in New Bottles', Film 39 (Spring I964), pp. 32-3.

'The Mass-Media - A Highbrow Illiteracy?', Views 4 (Spring 1964), pp. 49-59.

'Vote for Britain: A Cinemagoer's Guide to the General Election', Part I, Films and Filming

(April 1964), pp. 9-I4; Part 2, Films and Filming (May 1964), pp. I0-15; Part 3, Films and Filming (June 1964), pp. 38-43.

'Horror is My Business', Films and Filming (July 1964), pp. 7-8 (with John Cutts).

'Ten Years That Shook an Art', Film 40 (September 1964), pp. 22-3 (with Peter Armitage).

'The Impotence of Being Ernest', Views 8 (Summer 1965), pp. 76-80.

'Michael Powell', Movie I4 (Autumn 1965), pp. 17-20 (as O. O. Green).

'Loved One', Films and Filming (February I966, April I966), pp. I9-23; March 1966, pp. 37-40.

'Losey: Modesty and Eve', Films and Filming (April 1966), pp. 26-33.

'Losey: Puritan Maids', Films and Filming (May 1966), pp. 28-33.

'Two on a Tandem', Films and Filming (July I966), pp. 26-33. 
'Brain Drains: Drifters, Avant-Gardes and Kitchen Sinks', Cinema 3 (June I969), pp. 48-53. A Mirror for England: British Movies from Austerity to Affluence (Faber \& Faber, 1970).

'Shoot Out in Dean Street', Films and Filming (February 1972), pp. 4I-2.

'Swinging London: Canes and Guitars', ch. 3 in Sexual Alienation in the Cinema (Studio Vista, I972).

'O Lucky Man or the Advantages of a Clockwork Cheese', Film Comment (January-February I973), pp. 38-40.

'Britannia Waives the Rules', Film Comment (July-August I976), pp. 50-8.

'The Great British Phantasmagoria', Film Comment (May-June 1977), pp. 48-53.

'Aiming at the Archers', Positif (February I981), pp. 22-3.

'History Man Bites Lucky Jim', Films (November 198I), p. 24.

'On the Alternative Options of Burning an Illusion', Films (November 1982), p. 37.

'A Skeleton Key to Stephen Dwoskin - Outline for a Text Not Written', Monthly Film Bulletin (November I982), pp. 252-3.

'Out of the Looking Glass or a Phantasmagoric Mirror for England', Monthly Film Bulletin (February 1984), pp. 39-40.

'Black Narcissus (... and in Theory: Towards a Superficial Structuralism)', Monthly Film Bulletin (October 1984), pp. 313-16.

'Gainsborough: the Times of its Time', Monthly Film Bulletin (August 1985), pp. 259-6I.

'The Ploughman's Just Desserts', American Film (November 1985), pp. 48-54, 80.

'The Pre-war Bs: Rewards and Fairies', Film Comment (May-June I990), pp. 28-30.

'The Powell and Pressburger Mystery', Cineaste (December 1997), pp. I6-19. 